\title{
TINGKAT KESIAPAN PEMERINTAH DAERAH DALAM URUSAN KETENAGAKERJAAN: PERSPEKTIF PEGAWAI
}

\section{LEVEL OF REGIONAL GOVERNMENT READINESS IN MANPOWER AFFAIRS: PERSPECTIVE OF EMPLOYEES}

\author{
Henriko Tobing, Faizal Nasution \\ Pusat Penelitian dan Pengembangan, Kementerian Ketenagakerjaan RI \\ Jl. Jendral Gatot Subroto Kav. 51, Jakarta Selatan, DKI Jakarta \\ henrikotobing.ht@gmail.com,faiz10march@gmail.com
}

\begin{abstract}
ABSTRAK
Penelitian ini mencoba mengukur kesiapan pemerintah daerah dalam pelaksanaan urusan ketenagakerjaan melalui keberadaan Dinas Tenaga Kerja (Disnaker) di daerah. Pengumpulan data dilakukan melalui penyebaran kuesioner kepada 236 orang pegawai yang tersebar pada 7 wilayah di Indonesia yang diwakili oleh 1 Disnaker Provinsi dan 1 Disnaker Kabupaten/Kota didukung dengan pelaksanaan focus group discussion (FGD) di masing-masing wilayah. Tingkat kesiapan atau selanjutnya disebut Indeks Kesiapan (IK), diukur dari beberapa aspek manajemen meliputi: kesiapan Sumber Daya Manusia (SDM), Keuangan, Metode/Standar Prosedur Operasional (SOP), dan Sarana Prasarana. Metode analisis yang digunakan dalam penelitian ini adalah metode analisis kesenjangan (gap analysis) dan model penghitungan Customer Satisfaction Index (CSI) dengan dasar penilaian berupa skala persepsi (likert). Hasil penelitian menunjukkan bahwa secara umum tingkat kesiapan Disnaker masuk dalam kategori "memadai dengan perbaikan" dengan rata-rata nilai IK 0,62. Berdasarkan aspek, SOP memiliki tingkat kesiapan tertinggi dan masuk dalam kategori "memadai" dengan rata-rata nilai IK 0,67, SDM masuk kategori "memadai dengan perbaikan" dengan rata-rata nilai IK 0,64, Keuangan masuk kategori "memadai dengan perbaikan" dengan rata-rata nilai IK 0,61, dan yang terendah adalah Sarana Prasarana masuk kategori "memadai dengan perbaikan" dengan rata-rata nilai IK 0,58. Implikasi manajerial dari hasil penelitian ini adalah Kementerian Ketenagakerjaan bersama dengan institusi terkait dan pemerintah daerah agar lebih fokus meningkatkan kinerja Dinas Tenaga Kerja melalui perbaikan aspek-aspek dalam organisasi yang terlihat rendah seperti keuangan dan sarana Prasarana.
\end{abstract}

Kata Kunci: Indeks Kesiapan, Disnaker, Analisis Kesenjangan, Customer Satisfaction Index.

\begin{abstract}
This study tries to measure the readiness of Regional Governments in implementation of manpower affairs through the existence of the Regional Government of Manpower (Disnaker) in the regions. Data collection was carried out through the distribution of questionnaires to 236 employees spread across 7 regions in Indonesia represented by 1 Provincial Government of Manpower and 1 District / City Government of Manpower, supported by the implementation of focus group discussions (FGD). The level of readiness or hereinafter referred to as Readiness Index (IK) is measured from several aspects of management including the readiness of Human Resources (HR), Finance, Method/Standard Operating Procedures (SOP), and Infrastructure. The analytical method used in this study is the gap analysis method and the Customer Satisfaction Index (CSI) calculation model based on an assessment in the form of a perception scale (Likert). The results showed that the overall level of Disnaker readiness was considered to be "adequate with improvement" with average IK score 0.62. Based on aspects, SOP has the highest level of readiness and considered to be "adequate" with average IK score 0.67, HR aspect considered to be "adequate with improvement" with average IK score 0.64, Finance aspect considered to be "adequate with improvement" with average IK score 0.61, and the lowest score is Infrastructure aspect, considered to be "adequate with improvement" with average IK score 0.58. The managerial implication of the results of this study is that the Ministry of Manpower together with relevant institutions and local governments should focus more on improving the performance of the Regional Government of Manpower through improving aspects of the organization that appear to be inferior such as finance and infrastructure.
\end{abstract}

Keywords: Readiness Index, Disnaker, Gap Analysis, Customer Satisfaction Index. 


\section{PENDAHULUAN}

Meningkatnya tuntutan pada organisasi publik untuk bisa bekerja lebih efektif dan efisien serta mampu membuat keputusan yang tepat dalam menyelenggarakan layanan publik mendorong organisasi untuk mulai melakukan penilaian terhadap kinerja dirinya. Penilaian ini menjadi penting agar organisasi publik memahami dengan baik posisinya, bagaimana kondisinya, dan hal-hal apa saja yang dapat diperbaiki guna memastikan berjalannya tugas dan fungsi tersebut. Senada dengan hal tersebut, Rumelt (2013) dalam bukunya menyatakan bahwa hal mendasar dalam menyusun strategi kebijakan yang baik adalah memahami secara komprehensif apa yang sedang terjadi. Penilaian atau pengukuran ini merupakan isu penting, baik bagi kalangan praktisi maupun akademisi (Antony \& Bhattacharyya, 2010; Heckl \& Moormann, 2010; Hubbard, 2009; Sabiu et.al, 2019; Van Looy \& Shafagatova, 2016). Moorman menyatakan bahwa pengukuran merupakan bagian dari kegiatan pengawasan terhadap berlangsungnya proses bisnis, sementara Van Looy \& Shafagatova menyatakan bahwa penetapan pengukuran kinerja akan memastikan keselarasan antara proses bisnis dengan strategi bisnisnya. Beberapa pengukuran organisasi publik yang telah umum digunakan di Indonesia diantaranya adalah Indeks Persepsi Korupsi, Indeks Reformasi Birokrasi, Indeks Kemudahan Berusaha, Indeks Pelayanan Publik (Kemen PAN RI, 2017).

Kementerian Ketenagakerjaan RI sebagai salah satu organisasi publik berikut struktur vertikal di bawahnya yaitu Dinas Tenaga Kerja yang selanjutnya disebut Disnaker baik di Provinsi dan Kabupaten/Kota, berdasarkan Undang-Undang No. 23 tahun 2014 tentang Pemerintahan Daerah sebagaimana telah diubah dengan Undang-Undang No. 9 tahun 2015 mempunyai mandat untuk melaksanakan pelayanan kepada publik dalam urusan Ketenagakerjaan di daerah. Urusan Ketenagakerjaan yang dimaksud umumnya diakomodir oleh 4 (empat) bidang teknis yang ada di dalam Disnaker, yaitu Pelatihan dan Produktivitas Tenaga Kerja, Penempatan dan Perluasan Kesempatan Kerja, Hubungan Industrial dan Jaminan Sosial, serta Pengawas Ketenagakerjaan dan K3. Disnaker sebagai salah satu organisasi publik sudah tentu, suka atau tidak suka, harus melakukan penilaian terhadap kinerjanya sendiri baik dari sisi eksternal yaitu pelayanan kepada masyarakat, maupun sisi internal yaitu kesiapan organisasinya.

Undang-Undang No. 23 tahun 2014 merupakan perubahan dari ketentuan sebelumnya yaitu Undang-Undang No. 32 tahun 2004. Hal mendasar dari perubahan tersebut adalah banyaknya kewenangan yang dilimpahkan ke Pemerintah Provinsi di mana sebelumnya kewenangan lebih banyak terdapat di Kabupaten/Kota. Undang-Undang tersebut merubah peran Pemerintah Pusat kembali bertindak sebagai penentu kebijakan. Sifatnya hirarkis dalam kegiatan koordinasi, pembinaan dan pengawasan. Sebagai contoh kegiatan pengawasan penyelenggaraan kebijakan, di mana Pemerintah Pusat mengawasi Pemerintah Provinsi dan selanjutnya Pemerintah Provinsi mengawasi Pemerintah Kabupaten/Kota. Pemerintah terendah melakukan tugas Pemerintahan di atasnya melalui asas tugas pembantuan. Kewenangan penyelenggaraan urusan pemerintah ini sebagaimana terlampir.

Dalam Rencana Pembangunan Jangka Menengah Nasional (RPJMN) 2020-2024 (Bappenas, 2019), disebutkan bahwa penetapan Undang-Undang No. 23 tahun 2014 tentang Pemerintahan Daerah memunculkan berbagai tantangan baru dalam pengelolaan desentralisasi di Indonesia. Saat ini pelaksanaan kebijakan desentralisasi dan otonomi daerah masih sangat tergantung pada Pemerintah Pusat, terutama dari sisi transfer pendanaan, pengaturan regulasi serta pelaksanaan kebijakan. Pemerintah Daerah belum sepenuhnya mampu mengakses sumber pembiayaan lain selain anggaran dari pemerintah pusat. Selain itu, pelaksanaan kebijakan nasional di daerah belum optimal dilaksanakan, antara lain disebabkan masih rendahnya kapasitas pemerintahan daerah di berbagai sisi baik kelembagaan, keuangan, kapasitas aparatur, dan hambatan dari dinamika politik lokal. Terkait dengan dinamika politik dalam hubungannya dengan pengukuran kinerja, (Parwoto \& Halim, 2020) dalam penelitiannya menemukan bahwa dukungan politik yang kuat akan sangat membantu proses penyusunan sistem pengukuran kinerja pada kelembagaan pemerintah daerah.

Masalah lainnya terungkap berdasarkan hasil diskusi dengan beberapa pejabat Disnaker 
di daerah bahwa peran Disnaker masih sangat kecil dalam proses pembangunan daerah. Hal ini antara lain dindikasikan dengan dukungan anggaran di Disnaker yang relatif kecil bila dibandingkan sektor lainnya. Selain jumlahnya yang kecil, menjadi bahan revisi yang pertama jika ada kebijakan daerah yang membutuhkan tambahan anggaran di sektor lain yang lebih prioritas. Kondisi tersebut pada akhirnya berdampak juga pada pengalokasian SDM dan sarana prasarana di Disnaker. Hal seperti ini bisa disebabkan oleh prioritas kebijakan pembangunan di daerah bersangkutan atau memang selama ini output yang dihasilkan oleh Disnaker belum terlalu dirasakan manfaatnya.

Berkaitan dengan hal-hal tersebut, penelitian ini dilakukan untuk mengukur tingkat kesiapan Pemerintah Daerah dalam hal ini Disnaker dalam melaksanakan urusan ketenagakerjaan yang tertuang dalam UndangUndang No. 23 tahun 2014 berdasarkan perspektif pegawai. Hal ini relevan dan penting untuk dilakukan guna meningkatkan kinerja dan kontribusi Disnaker dalam proses pembangunan daerah dan sebagai bagian dari pelaksana kebijakan nasional di daerah.

\section{METODE PENELITIAN}

\section{A. Kerangka Pemikiran Penelitian}

Penelitian ini bertujuan untuk melihat tingkat kesiapan Disnaker dalam melaksanakan tugas dan fungsi urusan ketenagakerjaan. Kesiapan tersebut dilihat berdasarkan beberapa unsur manajemen sebagai aspek dalam organisasi yang berkaitan langsung dengan penilaian pegawai internal Disnaker. Unsur tersebut meliputi aspek sumber daya manusia (SDM), keuangan, dan standar prosedur operasional, serta aspek perlengkapan yang diterjemahkan sebagai sarana prasarana dalam hal dukungan peralatan untuk mencapai tujuan. Sedangkan kesiapananya diukur berdasarkan harapan dan kenyataan yang dirasakan oleh pegawai yang ada pada Disnaker tersebut.

Keempat aspek tersebut diterjemahkan dari teori klasik manajemen yaitu $5 M$. Menurut
Harrington Emerson dalam Pfiffner \& Presthus (1960), 5M merupakan lima unsur dalam ilmu manajemen yang sangat penting keberadaan dan perannya yang berguna untuk peningkatan sistem manajerial dan tercapainya target serta tujuan perusahaan. Lima unsur tersebut yaitu sumber daya manusia (Men), Uang (Money), bahan baku (Materials), peralatan/mesin (Machines) dan metode (Method) yang dalam penerapannya kelima unsur tersebut saling berkaitan erat satu sama lainnya.

SDM merupakan unsur yang paling vital karena manusia yang membuat perencanaan dan juga melakukan proses untuk mencapai tujuan perusahaan atau organisasi bersangkutan. Tanpa adanya sumber daya manusia, maka tidak ada proses kerja (Terry, 1964). Di dalam organisasi, manajemen SDM merupakan kebijakan dan praktek yang mencakup kegiatan perekrutaan, penyaringan, pelatihan, pemberian penghargaan dan penilaian dari suatu organisasi (Dessler, 2009). Sedangkan unsur keuangan menjadi suatu ukuran bagi organisasi dalam menjalankan seluruh aktivitas sehari-harinya. Dengan ketersediaan uang yang memadai maka manajemen organisasi akan lebih leluasa dalam melakukan sejumlah efisiensi untuk mencapai tujuan organisasi (Terry, 1964).

Metode atau standard operational prosedure (SOP) yang baku sangat berperan dalam menerapkan manajemen guna mengelola sejumlah unsur-unsur tersebut, dan di setiap unit organisasi memiliki fungsi pokok dan tugas, maupun job desk tersendiri yang saling berkaitan erat dalam menjalankan aktivitas organisasinya (Terry, 1964). Sedangkan unsur peralatan sebagai pendukung dalam menjalankan aktivitas organisasi, peran dan dukungan peralatan dibutuhkan sehingga dapat lebih cepat dan efisien, serta meminimalisir tingkat kesalahan manusia (Terry, 1964). Dalam hal ini unsur peralatan didefinisikan sebagai sarana prasarana bagi organisasi dalam menjalankan dan mendukung segala aktivitas yang dilakukan organisasi. 
Vol. 15 No. 1, Edisi Januari - Juni 2020 ISSN : $2722-8770$

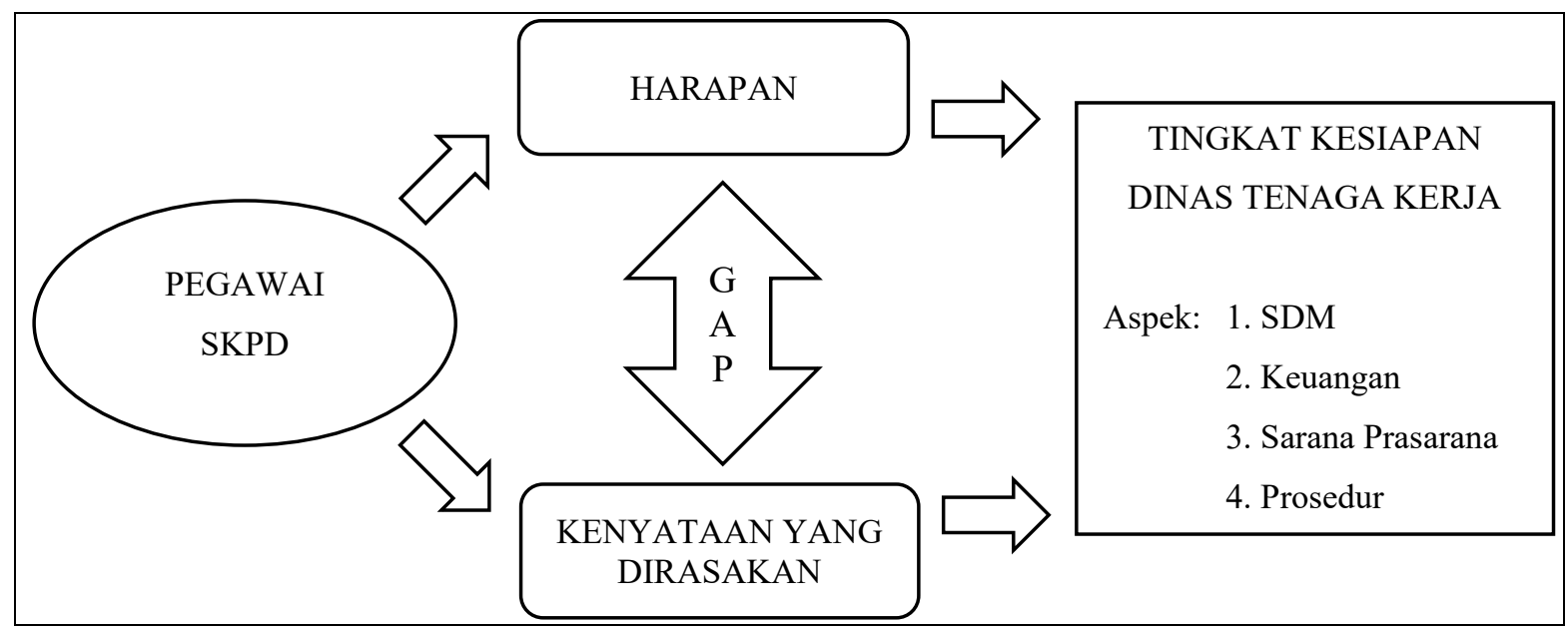

Gambar 1: Kerangka Pemikiran

Berdasarkan kerangka pemikiran tersebut, dapat dilihat bagaimana kenyataan atau keadaan aktual yang dirasakan oleh pegawai Disnaker dalam melaksanakan tugas-tugasnya; apa yang diharapkan, serta seberapa besar harapan tersebut akan dapat terwujud berdasarkan persepsi masing-masing individu. Sudut pandang tingkat kesiapan ini menggunakan 4 (empat) aspek yaitu SDM, Keuangan, Sarana Prasarana, dan Prosedur. Kesenjangan yang terjadi antara harapan dan kenyataan yang dirasakan, diukur dan menjadi suatu gambaran kondisi bagaimana tingkat kesiapan Disnaker sebagai organisasi Pemerintah Daerah dari perspektif pegawai SKPD dalam melaksanakan tugas dan fungsi urusan konkuren pada bidang ketenagakerjaan.

\section{B. Pengumpulan Data}

Penelitian ini menggunakan data primer yang dikumpulkan melalui kegiatan penyebaran kuesioner berbentuk hardcopy kepada sejumlah responden sebagai obyek yang diteliti. Guna melengkapi data dan informasi, setelah melakukan pengumpulan data primer ditindak lanjuti dengan focus group discussion (FGD).
Total responden dalam penelitian ini berjumlah 236 orang pegawai SKPD yang membidangi urusan Ketenagakerjaan, baik yang duduk pada jabatan struktural maupun fungsional. Pengumpulan data dilakukan pada keempat bidang teknis urusan ketenagakerjaan untuk mendapatkan gambaran kondisi Disnaker secara umum. Pemilihan responden yang merupakan pegawai pada Disnaker dilakukan atas pertimbangan bahwa merekalah yang paling memahami kondisi organisasi sesungguhnya dari dalam. Sedangkan peserta FGD adalah beberapa orang perwakilan dari masing-masing Disnaker.

Pengumpulan data dilakukan di 7 (tujuh) provinsi di Indonesia. Penentapan daerah sampel tersebut, didasarkan atas Peraturan Menteri Ketenagakerjaan No. 28 tahun 2016 tentang hasil pemetaan urusan Pemerintahan Daerah di bidang Ketenagakerjaan. Peraturan ini menetapkan beban kerja masing-masing dinas provinsi dan kabupaten/kota berdasarkan kategori besar, sedang, kecil dan sangat kecil. Lokus penelitian terdiri dari satu Disnaker provinsi dan satu Disnaker kabupaten/kota sebagai representasi dari setiap wilayah.

Tabel 1: Lokus Penelitian

\begin{tabular}{|c|l|l|}
\hline Kategori & \multicolumn{1}{|c|}{ Provinsi } & \multicolumn{1}{c|}{ Unit Kerja Responden } \\
\hline \multirow{4}{*}{ Besar } & \multirow{2}{*}{ Jawa Timur } & Dinas Tenaga Kerja dan Transmigrasi Prov. Jawa Timur \\
\cline { 3 - 3 } & & Dinas Perindustrian dan Tenaga Kerja Kab. Bangkalan \\
\cline { 2 - 3 } & \multirow{2}{*}{ Sulawesi Selatan } & Dinas Tenaga Kerja dan Transmigrasi Prov. Sulawesi Selatan \\
\cline { 3 - 3 } & & Dinas Tenaga Kerja Kab. Pangkep \\
\hline
\end{tabular}


Vol. 15 No. 1, Edisi Januari - Juni 2020 ISSN : $2722-8770$

\begin{tabular}{|c|c|c|}
\hline \multirow{4}{*}{ Sedang } & \multirow{2}{*}{$\begin{array}{l}\text { Kalimantan } \\
\text { Selatan }\end{array}$} & $\begin{array}{l}\text { Dinas Tenaga Kerja dan Transmigrasi Prov. Kalimantan } \\
\text { Selatan }\end{array}$ \\
\hline & & Dinas Koperasi, UMK dan Tenaga Kerja Kota Banjar Baru \\
\hline & \multirow{2}{*}{ Banten } & Dinas Tenaga Kerja dan Transmigrasi Prov. Banten \\
\hline & & Dinas Tenaga Kerja Kota Cilegon \\
\hline \multirow{4}{*}{ Kecil } & \multirow{2}{*}{ Bangka Belitung } & Dinas Tenaga Kerja Prov. Bangka Belitung \\
\hline & & Dinas Tenaga Kerja dan Transmigrasi Kab. Bangka Barat \\
\hline & \multirow{2}{*}{ Bali } & Dinas Tenaga Kerja dan ESDM Prov. Bali \\
\hline & & Dinas Tenaga Kerja dan Transmigrasi Kab. Gianyar \\
\hline \multirow{2}{*}{ Sangat Kecil } & \multirow{2}{*}{ Gorontalo } & $\begin{array}{l}\text { Dinas Penanaman Modal, ESDM dan Transmigrasi Prov. } \\
\text { Gorontalo }\end{array}$ \\
\hline & & Dinas Tenaga Kerja Kota Gorontalo \\
\hline
\end{tabular}

Sumber: Lokasi penelitian

Tabel 2: Jumlah Responden

\begin{tabular}{|l|c|}
\hline \multicolumn{1}{|c|}{ Provinsi } & Jumlah Responden \\
\hline Jawa Timur & 52 orang \\
\hline Sulawesi Selatan & 37 orang \\
\hline Kalimantan Selatan & 28 orang \\
\hline Banten & 38 orang \\
\hline Bangka Belitung & 15 orang \\
\hline Bali & 35 orang \\
\hline Gorontalo & 31 orang \\
\hline & 236 orang \\
\hline
\end{tabular}

Sumber: Jumlah responden
Pengumpulan data dilakukan dengan menggunakan kuesioner sebagai instrumen penelitian yang disusun dalam bentuk rangkaian pertanyaan terkait kesiapan Pemerintah Daerah dalam urusan ketenagakerjaan berdasarkan aspek-aspek yang diteliti, yaitu aspek SDM, keuangan, sarana prasarana dan standar prosedur operasional. Pertanyaan mengenai harapan dan kenyataan yang dirasakan oleh responden dalam kuesioner, dituangkan dalam bentuk nilai dengan menggunakan skala likert yang terdiri dari empat skala yaitu skala 1 (sangat tidak memadai), skala 2 (tidak memadai), skala 3 (memadai), dan skala 4 (sangat memadai). Penentuan jumlah skala ini dilakukan untuk mempermudah pengisian dan menghindari skala tengah sehingga tidak ada jawaban netral.

Tabel 3: Aspek Pertanyaan Kuesioner

\begin{tabular}{|c|l|l|}
\hline \multicolumn{1}{|c|}{ Aspek } & \multicolumn{1}{|c|}{ Atribut } & \multicolumn{1}{c|}{ Keterangan } \\
\hline \multirow{5}{*}{ Sumber Daya Manusia } & Jumlah SDM & $\begin{array}{l}\text { Banyaknya jumlah pegawai struktural } \\
\text { maupun fungsional }\end{array}$ \\
\cline { 2 - 3 } & Target Kerja SDM & $\begin{array}{l}\text { Kemampuan pencapaian target kerja Individu } \\
\text { maupun unit kerja }\end{array}$ \\
\cline { 2 - 3 } & Kompetensi SDM & $\begin{array}{l}\text { Kemampuan pencapaian target kerja, } \\
\text { kompetensi pegawai saat ini, dan program } \\
\text { peningkatan kapasitas dan kompetensi } \\
\text { pegawai }\end{array}$ \\
\hline \multirow{3}{*}{ Metode / Prosedur } & Petunjuk Teknis / S.O.P & $\begin{array}{l}\text { Ketersediaan petunjuk teknis maupun S.O.P } \\
\text { kerja }\end{array}$ \\
\cline { 2 - 3 } & Rencana Kerja & $\begin{array}{l}\text { Ketersediaan rencana kerja unit kerja } \\
\text { maupun pegawai }\end{array}$ \\
\cline { 2 - 3 } & Kerjasama Lintas Sektor & $\begin{array}{l}\text { Adanya kerjasama lintas sektor/unit sesuai } \\
\text { bidangnya }\end{array}$ \\
\hline
\end{tabular}


Vol. 15 No. 1, Edisi Januari - Juni 2020 ISSN : 2722 - 8770

\begin{tabular}{|l|l|l|}
\hline & Aplikasi Layanan Online & Adanya aplikasi layanan secara online \\
\hline \multirow{5}{*}{ Keuangan / Anggaran } & Besaran Total Anggaran & $\begin{array}{l}\text { Besaran total anggaran yang tersedia untuk } \\
\text { seluruh kegiatan sesuai bidangnya }\end{array}$ \\
\cline { 2 - 3 } & Anggaran Keg. Utama & $\begin{array}{l}\text { Besaran dan sumber anggaran yang } \\
\text { diperuntukan untuk kegiatan utama }\end{array}$ \\
\cline { 2 - 3 } Sarana Prasarana & $\begin{array}{l}\text { Angaran Keg. } \\
\text { Pendukung }\end{array}$ & $\begin{array}{l}\text { Besaran dan sumber anggaran yang } \\
\text { diperuntukan untuk kegiatan pendukung }\end{array}$ \\
\cline { 2 - 3 } & Penyerapan Anggaran & Tingkat penyerapan anggaran \\
\hline & Ketersediaan Sarana & $\begin{array}{l}\text { Ketersediaan sarana kerja seperti alat } \\
\text { pengolah data dan jaringan internet }\end{array}$ \\
\cline { 2 - 3 } & Ketersediaan Prasarana & $\begin{array}{l}\text { Ketersediaan prasarana kerja seperti ruang } \\
\text { kerja, ruang pendukung (untuk pelatihan, } \\
\text { mediasi, konsultasi, informasi, dsb), dan } \\
\text { kendaaraan dinas }\end{array}$ \\
\hline
\end{tabular}

Sumber: Hasil olahan data primer

\section{Metode Analisis Data}

Penetapan unsur manajemen sebagai indikator dalam merepresentasikan kesiapan dari sebuah lembaga/unit ini terdiri dari aspek manusia, sarana dan prasarana, sistem atau prosedur, dan anggaran atau keuangan. Hal yang diukur adalah seberapa besar harapan maupun kenyataan dari responden terhadap tingkat kesiapan organisasi berdasarkan aspek-aspek tersebut. Cukup banyak penelitian dengan bermacam-macam metode analisis data yang pernah dilakukan dengan tujuan untuk mengukur atau menyusun suatu ukuran tingkat kesiapan dengan data dasar menggunakan skala persepsi, di mana mereka membandingkan antara bagaimana yang mereka harapkan dengan apa yang mereka rasakan.

Analisis yang membandingkan antara harapan dan kenyataan atau umum disebut Model Gap Analysis atau analisis kesenjangan yang paling banyak dijadikan rujukan dalam riset adalah model yang dikembangkan oleh Parasuraman, Zeithaml, \& Berry (1988). Model ini dikenal sebagai service quality (Servqual) yang umum digunakan untuk mengetahui kesenjangan kualitas layanan. Parasuraman dkk. menyatakan bahwa terdapat kesenjangan kualitas pelayanan yang terjadi antara kualitas pelayanan yang aktual diberikan oleh suatu organisasi dengan kualitas pelayanan yang diharapkan oleh pelanggan. Dalam pengukurannya, kesenjangan didapatkan dari selisih antara skor kenyataan dengan skor harapan. Kesenjangan positif terjadi apabila nilai kenyataan lebih besar daripada nilai harapan, berarti organisasi telah memenuhi atau bahkan melebihi apa yang dianggap penting oleh individu. Sebaliknya, kesenjangan negatif terjadi apabila nilai kenyataan lebih kecil daripada nilai harapan, berarti organisasi belum memenuhi apa yang dianggap penting oleh individu. Boulding, Kalra, Staelin, \& Zeithaml (1993) menyebutkan bahwa semakin kecil terjadinya kesenjangan maka kualitas pelayanan yang dirasakan pelanggan akan semakin sesuai dengan harapan, sehingga dapat lebih menciptakan kepuasan pelanggannya.

Metode Customer Satisfaction Index (CSI) merupakan salah satu metode yang mengadopsi model analisis kesenjangan. Metode ini banyak digunakan dalam mengukur tingkat kepuasan pelanggan dengan melihat tingkat kepentingan dari aspek-aspek di dalam organisasi. Metode pengambilan nilainya menggunakan skala likert didasarkan pada skala harapan dan kenyataan yang dirasakan dan dikombinasikan dengan metode lain. (Hallencreutz \& Parmler, 2019; Turkyilmaz, Temizer, \& Oztekin, 2018; Zhang, Liu, Lu, \& Xiao, 2019). Dalam penelitian ini formula perhitungan CSI digunakan untuk mengukur kesiapan unsur-unsur manajemen dalam organisasi Ketenagakerjaan berdasarkan persepsi pegawai dengan menggunakan skala harapan dan skala kenyataan yang dirasakan oleh responden. Perhitungan ini kemudian diistilahkan sebagai Indeks Kesiapan (IK). 


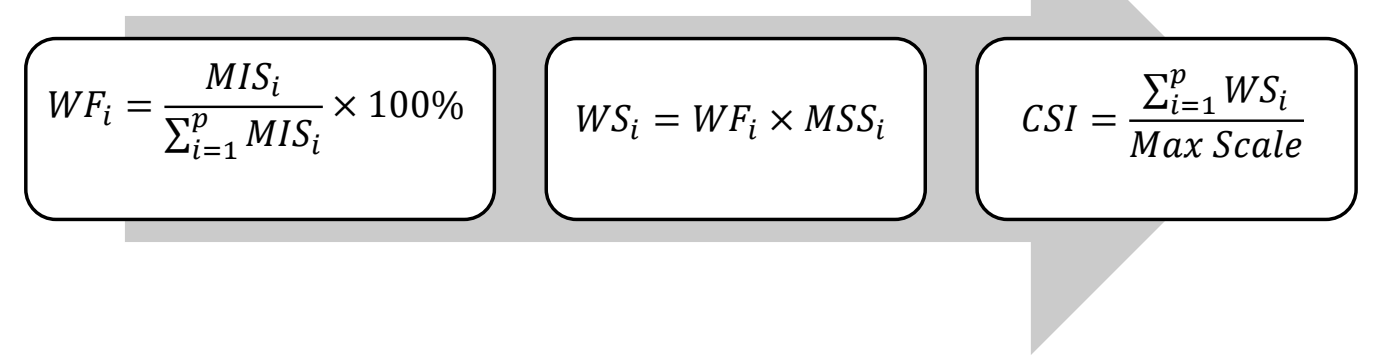

Gambar 2: Customer Satisfaction Index (CSI)

Sumber: Aritonang, 2005

Tahap pertama menghitung nilai Weighted Factor (WF) masing-masing responden yang berasal dari rata-rata nilai harapan, yaitu mean importance score (MIS) masing-masing responden terhadap satu aspek rata-rata nilai harapan secara umum responden pada aspek tersebut. Nilai ini untuk mengetahui berapa besar bobot penilaian harapan dari masingmasing responden terhadap suatu aspek. Tahap berikutnya yaitu menghitung nilai Weighted Score (WS) masing-masing responden yang berasal dari hasil perkalian antara WF dengan rata-rata nilai kenyataan yaitu mean satisfaction score (MSS) masing-masing responden terhadap satu aspek. Nilai ini digunakan untuk mengetahui besarnya tingkat kenyataan dengan memperhatikan bobot harapan masing-masing responden terhadap suatu atribut.
Tahap terakhir menghitung CSI dengan menjumlahkan seluruh WS dari semua responden terhadap atribut. Setelah itu total seluruh WS tersebut dibagi dengan nilai skala tertinggi untuk menghasilkan nilai dan batasan penilaiannya, dan skala tertingginya diberi nilai 4. Hasil dari IK tersebut dilihat dalam 5 (lima) kategori yang diadopsi berdasarkan kategori CSI pada tabel 4. Apabila rentang nilai 0,81-1,00, dalam katagori CSI termasuk sangat puas maka pada kategori IK diistilahkan dengan "Sangat memadai". Apabila dalam katagori CSI "cukup" pada kategori IK diistilahkan dengan "memadai dengan perbaikan".

Tabel 4: Kategori CSI

\begin{tabular}{|c|l|}
\hline Rentang Nilai & \multicolumn{1}{|c|}{ Kategori CSI } \\
\hline $0,82-1,00$ & Sangat Puas \\
\hline $0,66-0,81$ & Puas \\
\hline $0,50-0,65$ & Cukup \\
\hline $0,34-0,49$ & Tidak Puas \\
\hline $0,00-0,33$ & Sangat Tidak Puas \\
\hline
\end{tabular}

\begin{tabular}{|l|}
\hline \multicolumn{1}{|c|}{ Kategori IK } \\
\hline Sangat Memadai \\
\hline Memadai \\
\hline Memadai dengan Perbaikan \\
\hline Tidak Memadai \\
\hline Sangat Tidak Memadai \\
\hline
\end{tabular}

Sumber: Aritonang, 2005

\section{HASIL DAN PEMBAHASAN}

\section{A. Hasil Pengumpulan Data}

Hasil pengumpulan data dapat dilihat pada tabel 5. Berdasarkan hasil pengumpulan data tersebut, nilai harapan responden berkisar antara 3,08 hingga 3,66 atau secara kategori antara memadai hingga sangat memadai. Sedangkan nilai kenyataan yang dirasakan oleh responden berkisar antara 2,17 hingga 2,83 atau secara kategori, masuk dalam katagori IK: antara tidak memadai hingga memadai. Terjadi kesenjangan negatif pada seluruh aspek di seluruh wilayah penelitian, yang berarti bahwa organisasi tersebut belum memenuhi apa yang dianggap penting oleh individu. Kesenjangan negatif yang 
Vol. 15 No. 1, Edisi Januari - Juni 2020 ISSN : 2722 - 8770

paling besar terjadi pada aspek Sarana Prasarana dengan angka kesenjangan -1,06 dan aspek Keuangan denga angka kesenjangan -0,94.

Berdasarkan hasil tersebut, dapat dilihat bahwa secara umum seluruh responden memiliki persepsi harapan cukup besar terhadap kesiapan Disnaker dalam melaksanakan tugas dan fungsinya dalam urusan Ketenagakerjaan, namun kenyataan yang dirasakan saat ini masih jauh dari harapan terutama pada aspek Keuangan dan Sarana Prasarana.

Tabel 5: Hasil Pengumpulan Data

\begin{tabular}{|c|c|c|c|}
\hline Provinsi & $\begin{array}{c}\text { Rata-rata } \\
\text { Harapan }\end{array}$ & $\begin{array}{l}\text { Rata-rata } \\
\text { Kenyataan }\end{array}$ & $\begin{array}{c}\text { Kesenjanga } \\
n \\
(\mathrm{~K}-\mathrm{H}) \\
\end{array}$ \\
\hline \multicolumn{4}{|l|}{ Keseluruhan Aspek } \\
\hline 1. Jawa Timur & 3,38 & 2,57 & $-0,81$ \\
\hline 2. Sulawesi Selatan & 3,32 & 2,57 & $-0,75$ \\
\hline 3. Kalimantan Selatan & 3,27 & 2,37 & $-0,90$ \\
\hline 4. Banten & 3,46 & 2,48 & $-0,98$ \\
\hline 5. Bangka Belitung & 3,14 & 2,48 & $-0,66$ \\
\hline 6. Bali & 3,54 & 2,42 & $-1,12$ \\
\hline 7. Gorontalo & 3,51 & 2,57 & $-0,94$ \\
\hline Rata-rata & 3,37 & 2,49 & $-0,88$ \\
\hline \multicolumn{4}{|l|}{ Aspek SDM } \\
\hline 1. Jawa Timur & 3,35 & 2,62 & $-0,73$ \\
\hline 2. Sulawesi Selatan & 3,35 & 2,74 & $-0,61$ \\
\hline 3. Kalimantan Selatan & 3,30 & 2,44 & $-0,86$ \\
\hline 4. Banten & 3,47 & 2,43 & $-1,04$ \\
\hline 5. Bangka Belitung & 3,13 & 2,55 & $-0,58$ \\
\hline 6. Bali & 3,55 & 2,42 & $-1,13$ \\
\hline 7. Gorontalo & 3,52 & 2,70 & $-0,82$ \\
\hline Rata-rata & 3,38 & 2,56 & $-0,82$ \\
\hline \multicolumn{4}{|l|}{ Aspek SOP / Prosedur } \\
\hline 1. Jawa Timur & 3,35 & 2,69 & $-0,66$ \\
\hline 2. Sulawesi Selatan & 3,34 & 2,81 & $-0,53$ \\
\hline 3. Kalimantan Selatan & 3,28 & 2,65 & $-0,63$ \\
\hline 4. Banten & 3,45 & 2,45 & $-1,00$ \\
\hline 5. Bangka Belitung & 3,11 & 2,59 & $-0,52$ \\
\hline 6. Bali & 3,41 & 2,57 & $-0,84$ \\
\hline 7. Gorontalo & 3,50 & 2,83 & $-0,67$ \\
\hline Rata-rata & 3,35 & 2,66 & $-0,69$ \\
\hline \multicolumn{4}{|l|}{ Aspek Keuangan } \\
\hline 1. Jawa Timur & 3,31 & 2,56 & $-0,75$ \\
\hline 2. Sulawesi Selatan & 3,28 & 2,48 & $-0,80$ \\
\hline 3. Kalimantan Selatan & 3,30 & 2,21 & $-1,09$ \\
\hline 4. Banten & 3,45 & 2,64 & $-0,81$ \\
\hline
\end{tabular}


Vol. 15 No. 1, Edisi Januari - Juni 2020 ISSN : $2722-8770$

\begin{tabular}{|c|c|c|c|}
\hline 5. Bangka Belitung & 3,21 & 2,35 & $-0,86$ \\
\hline 6. Bali & 3,54 & 2,39 & $-1,15$ \\
\hline 7. Gorontalo & 3,48 & 2,41 & $-1,07$ \\
\hline Rata-rata & 3,37 & 2,43 & $-0,94$ \\
\hline \multicolumn{4}{|l|}{ Aspek Sarana Prasarana } \\
\hline 1. Jawa Timur & 3,51 & 2,43 & $-1,08$ \\
\hline 2. Sulawesi Selatan & 3,29 & 2,27 & $-1,02$ \\
\hline 3. Kalimantan Selatan & 3,20 & 2,17 & $-1,03$ \\
\hline 4. Banten & 3,47 & 2,38 & $-1,09$ \\
\hline 5. Bangka Belitung & 3,08 & 2,43 & $-0,65$ \\
\hline 6. Bali & 3,66 & 2,29 & $-1,37$ \\
\hline 7. Gorontalo & 3,55 & 2,33 & $-1,22$ \\
\hline Rata-rata & 3,39 & 2,33 & $-1,06$ \\
\hline
\end{tabular}

Sumber: Hasil olahan data primer

Secara umum, provinsi Bali, Banten, Gorontalo, dan Kalimantan Selatan secara berurutan memiliki nilai kesenjangan negatif yang paling besar di antara seluruh wilayah penelitian. Jika dilihat berdasarkan provinsi memang Provinsi Bali memiliki nilai kesenjangan negatif paling besar dibandingkan provinsi lainnya pada semua aspek. Provinsi Banten juga memiliki nilai kesenjangan negatif yang besar pada semua aspek kecuali pada aspek Keuangan. Sedangkan Provinsi Gorontalo dan Kalimantan Selatan memiliki kesenjangan negatif yang besar pada aspek Keuangan dan Sarana Prasarana. Hal yang cukup mengejutkan dapat dilihat pada aspek Sarana Prasarana, di mana seluruh Provinsi wilayah penelitian kecuali Provinsi Bangka Belitung memiliki nilai kesenjangan negatif yang sangat besar yang berkisar antara $-1,02$ hingga $-1,37$. Hal ini menunjukkan bahwa hampir seluruh responden memiliki harapan sangat besar terhadap aspek Sarana Prasarana dalam mendukung kinerjanya untuk melaksanakan tugas dalam urusan ketenagakerjaan, namun kenyataan yang dirasakan saat ini masih jauh dari harapan.

\section{B. Tingkat Kesiapan Dinas Tenaga Kerja}

Berdasarkan hasil pengolahan data, didapatkan hasil Indeks Kesiapan (IK) Dinas Tenaga Kerja sebagaimana tercantum pada tabel 6. Hasil tersebut menunjukkan bahwa rata-rata tingkat kesiapan Dinas Ketenagakerjaan di seluruh wilayah penelitian adalah "Memadai dengan Perbaikan" dengan rata-rata nilai IK 0,62. Hal ini dapat dilihat bahwa memang kegiatan pada Disnaker di daerah masih tetap dapat berjalan, namun hasil yang didapatkan masih belum dapat optimal sesuai harapan. Di dalamnya masih terdapat hal-hal yang perlu diperbaiki untuk mendapatkan output yang optimal hingga sesuai atau bahkan melebihi harapan. Hampir seluruh Provinsi wilayah penelitian menganggap tingkat kesiapannya masih "Memadai dengan Perbaikan".

Tabel 6: Indeks Kesiapan Dinas Tenaga Kerja

\begin{tabular}{|c|c|c|}
\hline Provinsi & $\begin{array}{c}\text { Indeks } \\
\text { Kesiapan }\end{array}$ & Kategori \\
\hline \multicolumn{3}{|l|}{ Keseluruhan Aspek } \\
\hline 1. Jawa Timur & 0,64 & Memadai dengan Perbaikan \\
\hline 2. Sulawesi Selatan & 0,65 & Memadai dengan Perbaikan \\
\hline 3. Kalimantan Selatan & 0,59 & Memadai dengan Perbaikan \\
\hline
\end{tabular}


Vol. 15 No. 1, Edisi Januari - Juni 2020 ISSN : 2722 - 8770

\begin{tabular}{|c|c|c|}
\hline 4. Banten & 0,62 & Memadai dengan Perbaikan \\
\hline 5. Bangka Belitung & 0,62 & Memadai dengan Perbaikan \\
\hline 6. Bali & 0,60 & Memadai dengan Perbaikan \\
\hline 7. Gorontalo & 0,64 & Memadai dengan Perbaikan \\
\hline Rata-rata & 0,62 & Memadai dengan Perbaikan \\
\hline \multicolumn{3}{|l|}{ Aspek SDM } \\
\hline 1. Jawa Timur & 0,66 & Memadai \\
\hline 2. Sulawesi Selatan & 0,69 & Memadai \\
\hline 3. Kalimantan Selatan & 0,61 & Memadai dengan Perbaikan \\
\hline 4. Banten & 0,61 & Memadai dengan Perbaikan \\
\hline 5. Bangka Belitung & 0,63 & Memadai dengan Perbaikan \\
\hline 6. Bali & 0,60 & Memadai dengan Perbaikan \\
\hline 7. Gorontalo & 0,68 & Memadai \\
\hline Rata-rata & 0,64 & Memadai dengan Perbaikan \\
\hline \multicolumn{3}{|l|}{ Aspek SOP / Prosedur } \\
\hline 1. Jawa Timur & 0,67 & Memadai \\
\hline 2. Sulawesi Selatan & 0,71 & Memadai \\
\hline 3. Kalimantan Selatan & 0,67 & Memadai \\
\hline 4. Banten & 0,61 & Memadai dengan Perbaikan \\
\hline 5. Bangka Belitung & 0,65 & Memadai dengan Perbaikan \\
\hline 6. Bali & 0,64 & Memadai dengan Perbaikan \\
\hline 7. Gorontalo & 0,71 & Memadai \\
\hline Rata-rata & 0,67 & Memadai \\
\hline \multicolumn{3}{|l|}{ Aspek Keuangan } \\
\hline 1. Jawa Timur & 0,64 & Memadai dengan Perbaikan \\
\hline 2. Sulawesi Selatan & 0,62 & Memadai dengan Perbaikan \\
\hline 3. Kalimantan Selatan & 0,56 & Memadai dengan Perbaikan \\
\hline 4. Banten & 0,67 & Memadai \\
\hline 5. Bangka Belitung & 0,58 & Memadai dengan Perbaikan \\
\hline 6. Bali & 0,60 & Memadai dengan Perbaikan \\
\hline 7. Gorontalo & 0,61 & Memadai dengan Perbaikan \\
\hline Rata-rata & 0,61 & Memadai dengan Perbaikan \\
\hline \multicolumn{3}{|l|}{ Aspek Sarana Prasarana } \\
\hline 1. Jawa Timur & 0,61 & Memadai dengan Perbaikan \\
\hline 2. Sulawesi Selatan & 0,57 & Memadai dengan Perbaikan \\
\hline 3. Kalimantan Selatan & 0,55 & Memadai dengan Perbaikan \\
\hline 4. Banten & 0,60 & Memadai dengan Perbaikan \\
\hline 5. Bangka Belitung & 0,61 & Memadai dengan Perbaikan \\
\hline 6. Bali & 0,57 & Memadai dengan Perbaikan \\
\hline
\end{tabular}


Vol. 15 No. 1, Edisi Januari - Juni 2020 ISSN : 2722 - 8770

\begin{tabular}{|l|c|l|}
\hline 7. Gorontalo & 0,58 & Memadai dengan Perbaikan \\
\hline Rata-rata & 0,58 & Memadai dengan Perbaikan \\
\hline
\end{tabular}

Sumber: Hasil olahan data primer

Aspek SOP merupakan aspek yang paling tinggi tingkat kesiapannya dibandingkan aspek lainnya. Rata-rata nilai IK seluruh Provinsi terhadap aspek ini 0,67, berarti dan dianggap telah "Memadai". Provinsi Sulawesi Selatan, Gorontalo, Jawa Timur, dan Kalimantan Selatan menganggap tingkat kesiapan terhadap aspek SOP telah "Memadai". Secara garis besar, persepsi responden terhadap aspek SOP ini sesuai dengan keadaan, yang pada umumnya sudah tersedia dan memadai serta mampu mengakomodir hampir seluruh kegiatan operasional Disnaker di daerah, meski dalam penerapannya masih ada prosedur kerja yang dianggap belum memadai. Beberapa hal yang perlu dilakukan perbaikan, yaitu petunjuk teknis/operasional yang sudah ada sebaiknya disesuaikan dengan perubahan kebijakan perundangan yang baru. Penyesuaian tersebut antara lain untuk menghindari tumpang tindih kewenangan.

Aspek SDM berdasarkan rata-rata nilai IK seluruh provinsi sebesar 0,64 dan dianggap "Memadai dengan Perbaikan". Provinsi Sulawesi Selatan, Gorontalo, dan Jawa Timur menganggap tingkat kesiapan terhadap aspek ini telah "Memadai", sedangkan Provinsi lainnya menganggap "Memadai dengan Perbaikan". Berdasarkan keadaan yang terjadi, dengan kondisi SDM saat ini sebenarnya masih dapat mengakomodir seluruh kegiatan operasional Disnaker di daerah, namun hasil yang didapat belum dapat optimal. Jumlah SDM dari tahun ke tahun cenderung menurun dan jumlah SDM saat ini khususnya Pegawai Fungsional dianggap kurang memadai karena tidak sebanding dengan jumlah dan beban pekerjaan yang ada. Hal ini terjadi disebabkan belum adanya pengadaan pegawai akibat dari moratorium pengadaan PNS, tingkat mutasi di daerah yang begitu dinamis, kurangnya minat untuk menjadi Pegawai Fungsional, proses birokrasi pengangkatan maupun penerimaan yang panjang, serta berkurangnya beberapa pegawai yang memasuki purna tugas.

Peningkatan kapasitas SDM dianggap cukup memadai karena kebanyakan unit kerja telah memperoleh bimbingan teknis, pelatihan dan peningkatan kemampuan. Namun peningkatan kapasitas SDM ini harus terus dilakukan, khususnya terhadap Pejabat Struktural yang kurang profesional karena memiliki latar belakang pendidikan dan pengalaman kerja yang tidak sesuai denagan bidang yang saat ini didudukinya. Kendala utama terhadap peningkatan kapasitas SDM ini yaitu keterbatasan anggaran yang disebabkan prioritas utama Pemerintah Daerah pada umumnya adalah untuk pembangunan infrastruktur dan pembangunan lainnya yang dianggap lebih prioritas.

Aspek Keuangan berdasarkan rata-rata nilai IK seluruh provinsi sebesar 0,61, dan dianggap "Memadai dengan Perbaikan". Hanya Provinsi Banten yang menganggap tingkat kesiapan terhadap aspek ini telah "Memadai". Berdasarkan keadaan yang terjadi, anggaran yang tersedia saat ini sebenarnya masih dapat mengakomodir seluruh kegiatan operasional Disnaker di daerah, namun hasil yang didapat belum dapat optimal. Masalah kekurangan anggaran menjadi isu sentral yang muncul di hampir seluruh wilayah penelitian, dan bisa dipastikan kekurangan tersebut tidak dapat dipenuhi karena fokus Pemerintah Daerah pada umumnya adalah untuk pembangunan infrastruktur dan lainnya yang dianggap lebih prioritas. Pada prinsipnya tanpa adanya pendanaan dari Pemerintah Pusat, Disnaker di daerah masih tetap dapat berjalan. Hal ini dapat dilihat pada tren data anggaran menunjukkan bahwa terjadi kenaikan proporsi APBD terhadap APBN, bahkan di beberapa daerah bidangbidang tertentu sudah tidak memperoleh APBN dengan konsekuensinya yaitu terjadinya penurunan output.

Kecenderungan porsi APBN yang menurun digantikan oleh kenaikan proporsi APBD utamanya terjadi di daerah-daerah yang memiliki Pendapatan Asli Daerah (PAD) tergolong sedang hingga tinggi, seperti di Provinsi Jawa Timur dan Banten. Pelaksanaan kegiatan masih berbasis pendekatan ketersediaan anggaran sehingga kurang fleksibel dalam berkreasi dan berinovasi dalam penyusunan kegiatan. Kegiatan yang dibiayai 
APBD tidak sama pada setiap tahunnya sesuai dengan program yang telah ditetapkan sesuai juknis penyusunan program dan anggaran dari Kementerian Dalam Negeri. Sedangkan kegiatan dari pusat yang dibiayai APBN relatif sama dari tahun ke tahun karena sudah ditentukan oleh Unit Teknis di Kementerian Ketenagakerjaan.

Aspek Sarana Prasarana berdasarkan ratarata nilai IK seluruh provinsi sebesar 0,58 dan dianggap "memadai dengan perbaikan" Aspek ini menjadi aspek yang dianggap paling tidak siap dalam urusan ketenagakerjaan. Sarana prasarana menjadi suatu aspek pendukung, di mana keberadaannya sangat dibutuhkan untuk menjalankan segala kegiatan operasional. Berdasarkan keadaan yang terjadi, sarana prasarana yang tersedia saat ini memang dianggap kurang memadai oleh sebagian besar responden. Namun demikian keterbatasan sarana prasarana tersebut masih dapat mengakomodir seluruh kegiatan operasional Disnaker di daerah.

Beberapa sarana dan prasarana yang dianggap kurang memadai antara lain beberapa tempat kerja Disnaker yang masih berstatus sewa, ruang kantor dan ruang pelayanan yang kurang layak dan terbatas, terdapat beberapa alat pengolah data yang tersedia kebanyakan sudah tidak berfungsi dan sebagian besar ketinggalan jaman, serta kendaraan dinas operasional yang masih terbatas jumlahnya sehingga menghambat tugas pelayanan. Hal ini disebabkan sedikitnya alokasi anggaran dari Pemerintah Daerah untuk menyediakan sarana dan prasarana kerja. Sedangkan pengadaan aset dari Pemerintah Pusat ke Daerah yang dilakukan secara top down, sistem transfernya rumit dan pada umumnya tanpa melihat kebutuhan daerah. Ketidaksesuaian tersebut, khusus terjadi dalam hal sarana pelatihan kerja, di beberapa wilayah sarana yang tersedia kurang memadai seperti ruang pelatihan kerja dan uji kompetensi yang kurang layak dan terbatas jumlahnya, serta peralatan pelatihan kerja di kejuruan tertentu kurang sesuai dengan perkembangan jaman dan kebutuhan dunia industri.

\section{KESIMPULAN}

Penelitian ini menunjukkan bahwa secara umum Pegawai SKPD memiliki harapan yang cukup besar terhadap kesiapan Disnaker dalam melaksanakan tugas dan fungsinya dalam urusan Ketenagakerjaan, namun kenyataan yang dirasakan saat ini masih jauh dari harapan terutama pada aspek Keuangan dan Sarana Prasarana. Secara keseluruhan tingkat kesiapan Disnaker di seluruh wilayah penelitian adalah memadai, namun masih butuh banyak perbaikan. Aspek yang paling tinggi tingkat kesiapannya hingga yang paling rendah yaitu aspek SOP, SDM, Keuangan, dan Sarana Prasarana. Aspek SOP merupakan aspek yang paling tinggi tingkat kesiapannya, sedangkan aspek Sarana Prasarana merupakan aspek yang paling rendah tingkat kesiapannya.

Pada umumnya SOP sudah tersedia dan memadai meski dalam penerapannya masih dianggap belum memadai serta dibutuhkan updating. Jumlah SDM cenderung menurun dan dianggap kurang memadai karena tidak sebanding dengan jumlah dan beban pekerjaan yang ada. Beberapa penyebabnya adalah mutasi, dan kurangnya minat menjadai pegawai fugsional. Selain itu keterbatasan jumlah pegawai fungsional, antara lain disebabkan oleh proses birokrasi pengusulan rekrut pegawai yang cukup panjang, dan berapa pegawsai fungsional melepaskan jabatan fungsionalnya, ketika yang bersangkutan diangkat menjadi pejabat struktural. Masalah SDM lainnya adalah peningkatan kapasitas SDM dianggap belum memadai, khususnya terhadap para Pejabat Struktural baru yang belum menguasai bidang tugasnya.

Masalah keuangan atau kekurangan anggaran masih menjadi isu sentral yang muncul di hampir seluruh wilayah. Proporsi APBD terhadap APBN kecenderungannya terus mengalami kenaikan, bahkan di beberapa daerah bidang-bidang tertentu sudah tidak memperoleh APBN dengan konsekuensinya yaitu penurunan output menurun. Sedangkan sarana prasarana yang tersedia dianggap kurang memadai disebabkan minimnya alokasi anggaran dari Pemerintah Daerah untuk menyediakan sarana dan prasarana kerja, serta sistem transfer aset dari Pemerintah Pusat ke Daerah yang rumit dan kurang menangkap kebutuhan daerah yang sebenarnya.

Pemerintah Pusat perlu mendukung Pemerintah Daerah dari sisi anggaran apabila memiliki target atau sasaran program yang dilakukan di daerah, khususnya diprioritaskan 
pada wilayah-wilayah yang memiliki PAD kecil atau dengan pertimbangan situasi Ketenagakerjaan tertentu. Perlu difokuskan peningkatan kinerja terhadap aspek-aspek dalam organisasi yang terlihat rendah seperti Keuangan dan Sarana Prasarana. Perbaikan aspek Sarana Prasarana yang dianggap paling tidak siap dalam menjalankan urusan Ketenagakerjaan di daerah, seperti melakukan pengadaan peralatan dan ruangan, serta melakukan pembaruan menyesuaikan dengan perkembangan jaman dan industri. Menanggapi masalah isu kekurangan anggaran dibutuhkan inovasi dan kreativitas guna meningkatkan kinerja atau target program. Peningkatan kinerja atau target program agar dapat terpenuhi diperlukan penambahan jumlah SDM pada bidang-bidang yang membutuhkan, serta terus melakukan peningkatan kapasitas SDM, khususnya terhadap Pegawai Fungsional dan Pejabat Struktural yang belum menguasai bidangnya. Penguatan SOP tetap perlu dilakukan seperti perbaikan petunjuk teknis maupun operasional yang sudah ada disesuaikan dengan perubahan kebijakan perundangan yang baru, untuk menghindari terjadinya tumpang tindih kewenangan dan untuk meningkatkan efektivitas pelaksanaan kegiatan.

\section{DAFTAR PUSTAKA}

Antony, J. P., \& Bhattacharyya, S. (2010). Measuring organizational performance and organizational excellence of SMEs Part 2: An empirical study on SMEs in India. Measuring Business Excellence, 14(3), 42-52. https://doi.org/10.1108/136830410110742 09

Aritonang, L. R. (2005). Pengukuran dan Penganalisisan Kepuasan Pelanggan. Jakarta: Gramedia.

Bappenas. (2019). Rencana Pembangunan Jangka Menengah Nasional 2020 - 2024. Kementerian PPN/ Bappenas. https://doi.org/10.1017/CBO97811074153 24.004

Boulding, W., Kalra, A., Staelin, R., \& Zeithaml, V. A. (1993). A Dynamic Process Model of Service Quality: From Expectations to Behavioral Intentions. Journal of Marketing Research. https://doi.org/10.2307/3172510
Daerah, U.-U. N. 32 T. 2004 T. P. (2004). Undang-Undang No 32 Tahun 2004 Tentang Pemerintah Daerah. Dpr, 249. Retrieved from http://www.dpr.go.id/dokjdih/document/u $\mathrm{u} / 33 . \mathrm{pdf}$

Dessler, G. (2009). Personnel planning and recruiting. In A framework for human resource management.

Hallencreutz, J., \& Parmler, J. (2019). Important drivers for customer satisfaction-from product focus to image and service quality. Total Quality Management and Business Excellence, $0(0), 1-10$. https://doi.org/10.1080/14783363.2019.15 94756

Heckl, D., \& Moormann, J. (2010). Handbook on Business Process Management 2. Handbook on Business Process Management 2, (August 2010). https://doi.org/10.1007/978-3-642-019821

Hubbard, G. (2009). Measuring organizational performance: Beyond the triple bottom line. Business Strategy and the Environment, 18(3), 177-191. https://doi.org/10.1002/bse.564

Kemen PAN RI. Peraturan Menteri Pendayagunaan Aparatur Negara Dan Refeormasi Birokrasi RI Nomor 17 Tahun 2017 Pedoman Penilaian Kinerja Unit Penyelenggara Pelayanan Publik. , (2017).

Parasuraman, A., Zeithaml, V. A., \& Berry, L. L. (1988). SERQUAL: A Multiple-Item scale for Measuring Consumer Perceptions of Service Quality. Journal of Retailing. https://doi.org/10.1016/S01482963(99)00084-3

Parwoto, \& Halim, A. (2020). The Effects of Organizational and Political Factors on the Development of Performance Measurement System ( PMS ) of Local Government Institutions. Journal of Accounting and Investment, 21(2), 217239. https://doi.org/10.18196/jai.2102146

Pemerintah Republik Indonesia. (2014). Undang-Undang Republik Indonesia Nomor 23 tahun 2014 tentang Pemerintahan Daerah. Kementerian 
Sekretariat Negara RI.

https://doi.org/10.1017/CBO97811074153 24.004

Pfiffner, J. M., \& Presthus, R. V. (1960). Public Administration (xiii). New York: The Ronald Press.

Rumelt, R. (2013). Good Strategy Bad Strategy: The Difference and Why It Matters.

Sabiu et.al, M. S. (2019). The Mediating Role of Ethical Climate in the Relationship Between Performance Appraisal and Organizational Performance. International Journal of Public Administration, 42(8), 642-653. https://doi.org/10.1080/01900692.2018.14 98105

Terry, G. R. (1964). Principles of Management (4th ed.). Homewood: IRWIN.
Turkyilmaz, A., Temizer, L., \& Oztekin, A. (2018). A causal analytic approach to student satisfaction index modeling. Annals of Operations Research, 263(1-2), 565-585. https://doi.org/10.1007/s10479016-2245-x

Van Looy, A., \& Shafagatova, A. (2016). Business process performance measurement: a structured literature review of indicators, measures and metrics. SpringerPlus, 5(1), 1-24. https://doi.org/10.1186/s40064-016-34981

Zhang, C., Liu, Y., Lu, W., \& Xiao, G. (2019). Evaluating passenger satisfaction index based on PLS-SEM model: Evidence from Chinese public transport service. Transportation Research Part A: Policy and Practice, 120(December 2017), 149164.

https://doi.org/10.1016/j.tra.2018.12.013 
Tabel 7: Lampiran Kewenangan Penyelenggaraan Pemerintah Daerah Urusan Ketenagakerjaan

\begin{tabular}{|c|c|c|}
\hline Bidang Teknis & Daerah Provinsi & Daerah Kabupaten /Kota \\
\hline $\begin{array}{l}\text { Pengawasan } \\
\text { Ketenagakerjaan }\end{array}$ & $\begin{array}{l}\text { Penyelenggaraan Pengawasan } \\
\text { Ketenagakerjaan }\end{array}$ & Tidak ada Kewenangan \\
\hline $\begin{array}{l}\text { Pelatihan Kerja dan } \\
\text { Produktivitas Tenaga } \\
\text { Kerja }\end{array}$ & $\begin{array}{l}\text { 1. Pelaksanaan pelatihan } \\
\text { berdasarkan klaster kompetensi } \\
\text { 2. Pelaksanaan akreditasi lembaga } \\
\text { pelatihan kerja. } \\
\text { 3. Konsultansi produktivitas pada } \\
\text { perusahaan menengah. } \\
\text { 4. Pengukuran produktivitas } \\
\text { tingkat Daerah provinsi. }\end{array}$ & $\begin{array}{ll}\text { 1. } & \text { Pelaksanaan pelatihan } \\
\text { berdasarkan unit kompetensi. } \\
\text { 2. Pembinaaan lembaga pelatihan } \\
\text { kerja swasta. } \\
\text { 3. Perizinan dan pendaftaran } \\
\text { lembaga pelatihan kerja. } \\
\text { 4. Konsultansi produktivitas pada } \\
\text { perusahaan kecil. } \\
\text { 5. Pengukuran produktivitas } \\
\text { tingkat Daerah kabupaten/kota. }\end{array}$ \\
\hline $\begin{array}{l}\text { Penempatan Tenaga } \\
\text { Kerja }\end{array}$ & $\begin{array}{l}\text { 1. Pelayanan antar kerja lintas } \\
\text { Daerah kabupaten/kota dalam } \\
1 \text { (satu) Daerah provinsi. } \\
\text { 2. Penerbitan izin LPTKS lebih } \\
\text { dari 1 (satu) Daerah } \\
\text { kabupaten/kota dalam 1 (satu) } \\
\text { Daerah provinsi. } \\
\text { 3. Pengelolaan informasi pasar } \\
\text { kerja dalam 1 (satu) Daerah } \\
\text { provinsi. } \\
\text { 4. Perlindungan TKI di luar negeri } \\
\text { (pra dan purna penempatan) di } \\
\text { Daerah provinsi. } \\
\text { 5. Pengesahan RPTKA } \\
\text { perpanjangan yang tidak } \\
\text { mengandung perubahan jabatan, } \\
\text { jumlah TKA, dan lokasi kerja } \\
\text { dalam 1 (satu) Daerah provinsi. } \\
\text { 6. Penerbitan perpanjangan IMTA } \\
\text { yang lokasi kerja lebih dari 1 } \\
\text { (satu) Daerah kabupaten/kota } \\
\text { dalam 1 (satu) Daerah provinsi. }\end{array}$ & $\begin{array}{l}\text { 1. Pelayanan antar kerja di Daerah } \\
\text { kabupaten/kota } \\
\text { 2. Penerbitan izin LPTKS dalam 1 } \\
\text { (satu) Daerah kabupaten/kota. } \\
\text { 3. Pengelolaan informasi pasar } \\
\text { kerja dalam Daerah } \\
\text { kabupaten/kota. } \\
\text { 4. Perlindungan TKI di luar negeri } \\
\text { (pra dan purna penempatan) di } \\
\text { Daerah kabupaten/kota } \\
\text { 5. Penerbitan perpanjangan IMTA } \\
\text { yang lokasi kerja dalam 1 (satu) } \\
\text { Daerah kabupaten/kota. }\end{array}$ \\
\hline Hubungan Industrial & $\begin{array}{ll}\text { 1. } & \text { Pengesahan } \\
\text { peraturanperusahaan } \\
\text { danpendaftaran perjanjiankerja } \\
\text { bersama untuk yangmempunyai } \\
\text { wilayah kerjalebih dari 1 } \\
\text { (satu)kabupaten/ kota dalam 1 } \\
\text { (satu)Daerah provinsi. } \\
\text { 2. Pencegahan dan penyelesaian } \\
\text { perselisihan hubungan } \\
\text { industrial, mogok kerja dan } \\
\text { penutupan perusahaan yang } \\
\text { berakibat/berdampak pada } \\
\text { kepentingan di 1 (satu) Daerah } \\
\text { provinsi. } \\
\text { 3. Penempatan upah minimum } \\
\text { provinsi (UMP), upah } \\
\text { minimum sektoral provinsi }\end{array}$ & 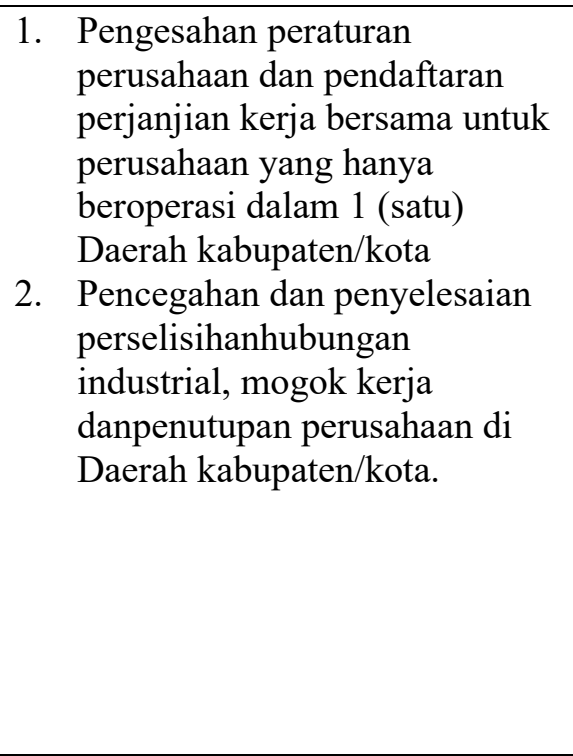 \\
\hline
\end{tabular}




\begin{tabular}{|l|l|l|}
\hline & $\begin{array}{l}\text { (UMSP), upah minimum } \\
\text { kabupaten/kota (UMK) dan } \\
\text { upah minimum sektoral } \\
\text { kabupaten/kota (UMSK). }\end{array}$ & \\
\hline
\end{tabular}

Sumber: Undang-undang No. 23 tahun 2014 tentang Pemerintahan Daerah 